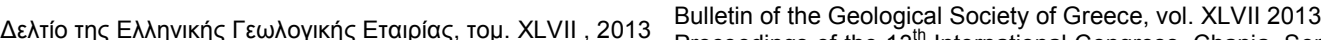
$\Delta$.

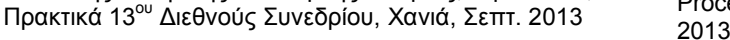

\title{
ANALYSIS OF TEMPORAL HYDROCHEMICAL AND ISOTOPIC VARIATIONS IN SPRING WATERS OF EASTERN PELOPONNESUS (GREECE)
}

\author{
Matiatos I. and Alexopoulos A. \\ Faculty of Geology and Geoenvironment - National and Kapodistrian University of Athens, 15784 \\ Panepistimiopolis, Athens, Greece
}

\begin{abstract}
The temporal variation of groundwater hydrochemistry has been used to support observations on the nature of groundwater circulation inside geological terrains of various lithological formations in Eastern Peloponnesus. In the present study, variations in groundwater physical-chemical properties such as electric conductivity, $\mathrm{CO}_{2}$ partial pressure, and calcite saturation index were used to give indications with regard to the nature of the geological formation, the groundwater residence time, and the mode of water circulation inside the hydrogeological systems. Additional isotopic values $\left(\delta^{18} O\right)$ were defined in order to support the aforementioned objectives. The seasonal variations of these properties during three years of monitoring were determined for individual springs appearing in the geological setting of Argolis peninsula, which is mostly composed of carbonate (karstificated in places), ophiolitic and flysch formations. The variation of the parameters was also approached by calculating the coefficient of variation used to detect whether the groundwater flow is of diffuse or/and conduit type. Coefficient of variation values of less than 5\% were considered as indicative of the diffuse flow type and therefore a long contact residence time, while higher values were associated with fast-flowing water. However, the isotopic measurements and the overall hydrochemical analysis combined with in situ observations, related to the flow characteristics of the springs, revealed that a spring can be fed by a common diffuse type system although it shows a rather high coefficient of variation.
\end{abstract}

Key words: Coefficient of variation, hydrochemistry, stable isotopes, groundwater, flow system.

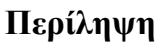

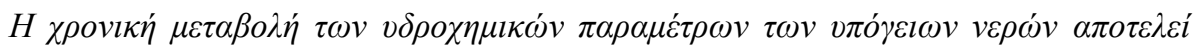

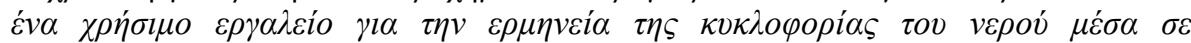

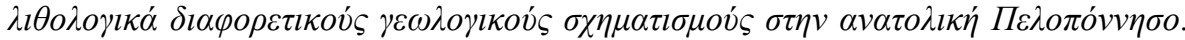

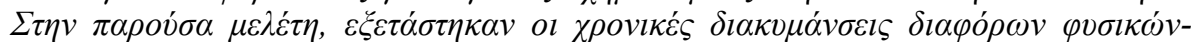

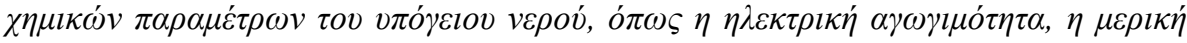

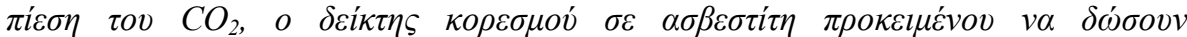

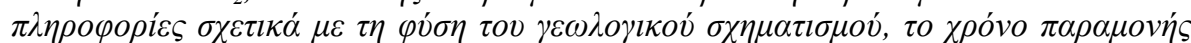

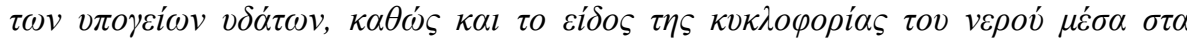

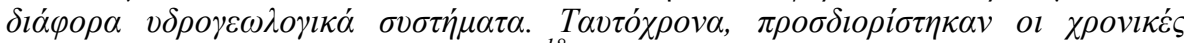

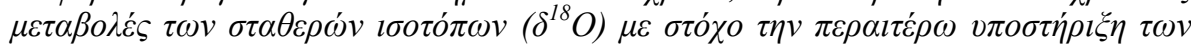

$\underline{\text { XLVII, No } 2-750}$ 


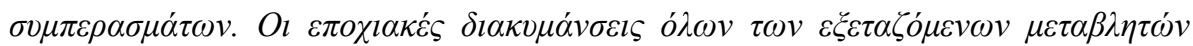

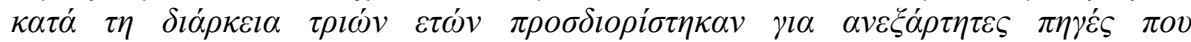

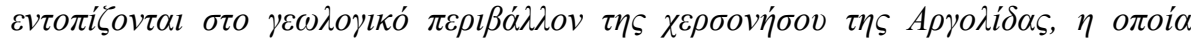

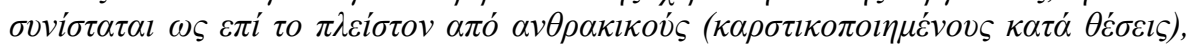

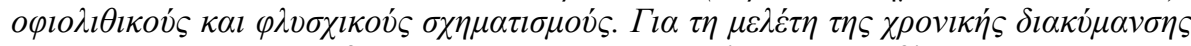

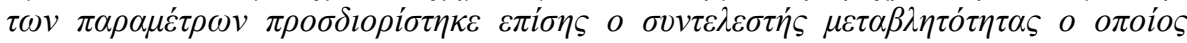

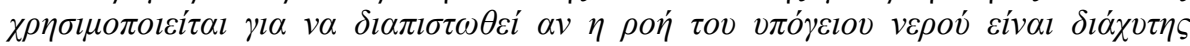

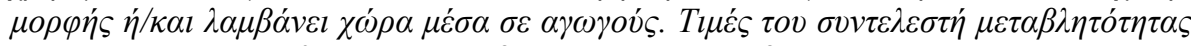

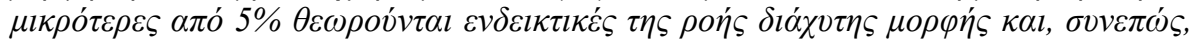

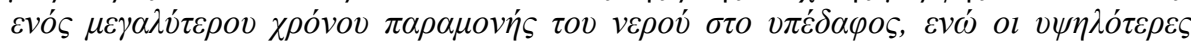

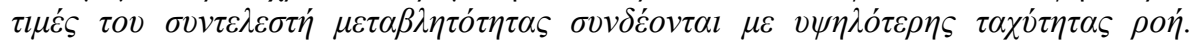

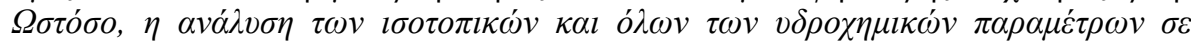

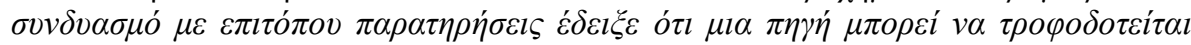

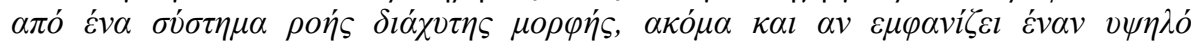
$\sigma v v \tau \varepsilon \lambda \varepsilon \sigma \tau \eta \dot{~} \mu \varepsilon \tau \alpha \beta \lambda \eta \tau o ́ \tau \eta \tau \alpha \varsigma$.

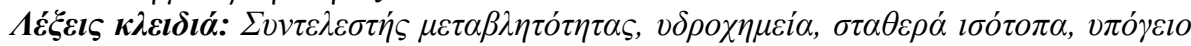

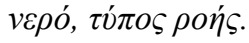

\section{Introduction}

Aquifers often discharge their water through large or small discharge springs. In regions where the ground water lies at shallow depths and where there is much localized recharge through sinking streams, the springs often show considerable seasonal variation in their physical-chemical characteristics. On the other hand, springs originating from higher depths showing possible fluctuations in discharge tend to maintain their physical-chemical characteristics constant in time (Liu et al., 2007; Shuster and White, 1971).

Groundwater flow is mainly determined by the regional geology. The stratigraphic position of the water hosting geological formations with respect to non-permeable capping, and large structural features controlling the position of recharge and discharge areas determine the subsurface hydrogeological conditions. Within a particular hydrogeological setting, groundwater systems may consist of primary or/ and secondary porosity in the forms of small fractures, joints, bedding planes and intergranular matrix largely unmodified by solution, or there may be a well integrated system of pipes and conduits (White, 2007; Gabrovsek and Dreybrodt, 2001; Ternan, 1974; Newson, 1972; Shuster and White, 1971). There are two end member groundwater flow systems (Singhal and Gupta, 2010; Shuster and White, 1971): 1) a diffuse flow (Darcian) in granular aquifers or in fractured aquifers along small interconnected openings measured in centimeters or less and 2) a conduit (turbulent) flow through integrated conduit systems with water flowing, often turbulently, through solution passages and fractures measured in centimeters to meters. The flow characteristics in carbonate rocks can be explained by discrete fracture flow, equivalent porous medium and double porosity models. A 'triple porosity' model has also been conceptualized in well developed karst aquifers consisting of matrix, fracture and conduit porosities (Kresic, 2007).

The objective of the present study is to investigate the variations in the hydrochemical and isotopic parameters of small discharge spring waters occurring in Argolis peninsula and to relate these variations to the type of flow system. Emphasis has been given on the geochemistry of the species and their statistically approached variation with season. Moreover, the identification of the flow system has given insight in the residence time of the groundwater in the geological formations.

\section{Geology - Hydrogeology}

As illustrated in the geological map (Figure 1), the largest part of the peninsula is occupied by the thick bedded limestones of Trapezona (Triassic-Jurassic age) with cherts and coarse-grained 
carbonate and ophiolitic breccias in the upper parts (Baumgartner, 1985). In the lower parts, volcanic formations were identified at many sites (Gaitanakis and Photiades, 1991; Renz, 1906). The ophiolitic mélange consisting mainly of pillow lavas and dolerites, and locally of cherts, siltstones, serpentinised mafic and ultramafic rocks, is typical in the peninsula. A flysch tectonic mélange characterised mainly by the presence of silts, sandstones and marls, occupies the largest part of Adheres mountain ridge. In this matrix, turiditic rocks of different lithologies, such as volcanic rocks, radiolarites, limestones, granodiorites (Photiades and Keay, 2000) pyroclastic rocks, andesites, dolomites (Aranitis, 1963), quartz sandstones, serpentinites and basalts (Clift and Robertson, 1989), are present. A 'post-Ypresian' flysch, which represents alterations of calcareous schists, marls, sandy marls, sandstones, conglomerates and limestones, covers mainly the NafplioLygourio basin (Kantas, 1991; Baumgartner, 1985). 'Akros formation' made up of neritic limestones of Cretaceous age, which successively become pelagic in the upper parts, and followed by marls and flysch outcrop mainly in the foothills of Mountains Arachnaio and Dhidhima (Decrouez, 1975). At the bottom of the formation, there is a tectonic mélange (Heliokastro area) of 'sheared' serpentinites and clastic slices of several rocks, such as dunits, basalts, cherts and limestones (Gaitanakis and Photiades, 1993; Photiades and Economou, 1991).

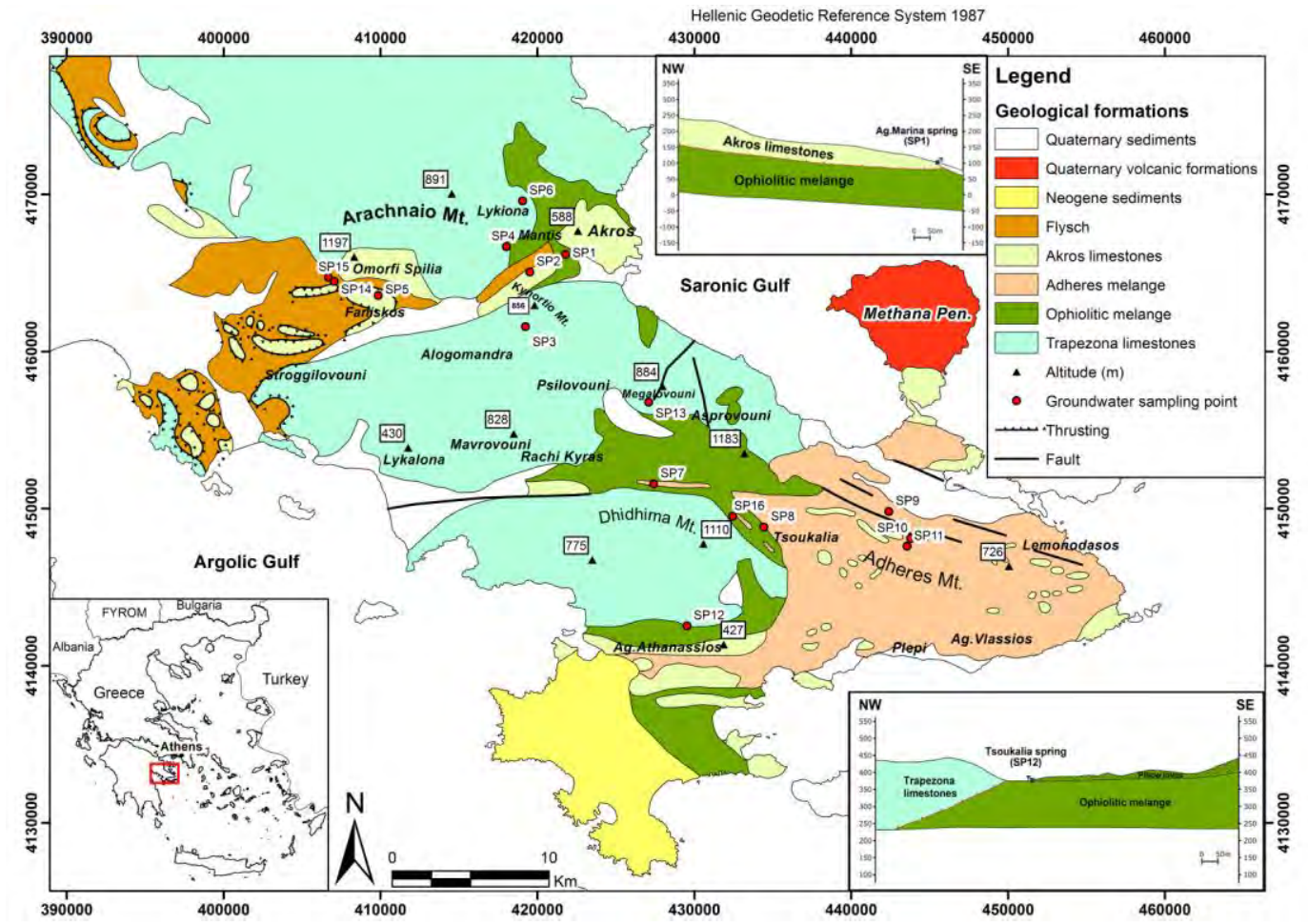

Figure 1 - Geological map of the study area, the location of the groundwater sampling sites and cross sections of two representative springs.

Neogene deposits of Miocene-Pliocene age occupy the Porto Cheli-Kranidi geological trough, in the southwestern part of the peninsula (Gaitanakis and Photiades, 2007). The sequence includes calcareous marls, marly limestones and conglomerates with sandstones intercalations. A quaternary volcanic formation consisting of loose volcanic sediments with tuff blocks and dacide and andesite domes (Fytikas et al., 1980), covers almost the entire Methana peninsula. Finally, recent deposits of Quaternary age, composed of alluvial fans, debris cones and loose sediments of silts, sands and pebbles are mainly lying inside the regional basins of the peninsula. 
In the absence of recorded aquifers' hydraulic parameters, a modified qualitative hydrolithological classification (Matiatos and Alexopoulos, 2011) of the aforementioned geological formations has been used to define the hydrogeological status in the peninsula. Hence, the geological formations have been classified in the following categories and subcategories (Table 1):

Table 1 - Hydrolithological classification of the geological formations in the study area and spring water sampling sites.

\begin{tabular}{|c|c|c|c|}
\hline Category & Subcategory & Geological formations & $\begin{array}{l}\text { Spring water } \\
\text { sampling site }\end{array}$ \\
\hline $\begin{array}{l}\text { Aquifers in which } \\
\text { flow is mainly in- } \\
\text { ter-granular }\end{array}$ & $\begin{array}{l}\text { Local productive aqui- } \\
\text { fers of small thickness or } \\
\text { extensive but moderately } \\
\text { productive aquifers }\end{array}$ & $\begin{array}{l}\text { Recent deposits (alluvi- } \\
\text { al fans, debris cones, } \\
\text { loose sediments of silts, } \\
\text { sands and pebbles) }\end{array}$ & SP2 \\
\hline \multirow{2}{*}{$\begin{array}{l}\text { Fissured aquifers } \\
\text { with secondary po- } \\
\text { rosity }\end{array}$} & $\begin{array}{l}\text { a. Extensive aquifers } \\
\text { with high productivity }\end{array}$ & $\begin{array}{l}\text { Limestones of Triassic- } \\
\text { Eocene age }\end{array}$ & $\begin{array}{l}\text { SP1, SP12, SP14, } \\
\text { SP15 }\end{array}$ \\
\hline & $\begin{array}{l}\text { b. Local productive aq- } \\
\text { uifers of small thickness } \\
\text { or extensive but moder- } \\
\text { ately productive aquifers }\end{array}$ & $\begin{array}{l}\text { Limestones of limited } \\
\text { extent inside the flysch } \\
\text { formations and the tec- } \\
\text { tonic mélange } \\
\text { Pelagic limestones of } \\
\text { Mesozoic age }\end{array}$ & SP9 \\
\hline \multirow[t]{2}{*}{$\begin{array}{l}\text { Fissured or granular } \\
\text { rocks forming in- } \\
\text { significant aquifers } \\
\text { or strata with essen- } \\
\text { tially no groundwa- } \\
\text { ter resources }\end{array}$} & $\begin{array}{l}\text { a. Local or extensive } \\
\text { aquifers with low } \\
\text { productivity }\end{array}$ & $\begin{array}{l}\text { Neogene sediments } \\
\text { Ophiolitic mélange }\end{array}$ & $\begin{array}{l}\text { SP5 } \\
\text { SP3, SP4, SP6, } \\
\text { SP7, SP8, SP13, } \\
\text { SP16 } \\
\text { SP10, SP11 }\end{array}$ \\
\hline & $\begin{array}{l}\text { b. Strata with essentially } \\
\text { no groundwater re- } \\
\text { sources }\end{array}$ & $\begin{array}{l}\text { Quaternary volcanic } \\
\text { formations }\end{array}$ & \\
\hline
\end{tabular}

The complex stratigraphy and the tectonic activity of the area have given the Argolis peninsula a substantial lithological heterogeneity in horizontal and vertical directions, which has led to the formation of independent aquifer systems and the appearance of a number of individual springs mainly of small discharge allocated in carbonate formations, as well as in less permeable lithologies, such as the ophiolitic mélange and the flysch sediments (Figure 1). The latter is evidenced by the presence of springs as well as of numerous wells and boreholes.

In situ geological and hydrogeological observations have revealed that the majority of the water bearing geological formations appearing in the peninsula show primary or/ and secondary porosity. Therefore, the groundwater systems occurring in them are expected to have diffuse flow through small fractures and the granular matrix of the rock, where the water seeps slowly through the aquifers. On the contrary, groundwater flow in conduits is expected to be dominant in the karstified carbonate formations, such as those observed in the Arachnaio and Dhidima Mountains.

\section{Methodology}

The present study examines the isotopic and physical-chemical characteristics of 16 spring sites, allocated in the Argolis peninsula to evaluate the sensitivity of processes to environmental change induced by geochemical factors. The campaign was carried out between March 2005 and March 2008, and the springs were continually monitored in situ for temperature, alkalinity, $\mathrm{pH}$ and electrical conductivity (EC). Moreover, all the springs were sampled at their mouth in order to 
minimise the groundwater exposure to ambient air and evaporation. Laboratory major ion analyses $\left(\mathrm{Ca}, \mathrm{Mg}, \mathrm{Na}, \mathrm{K}, \mathrm{NO}_{3}, \mathrm{Cl}, \mathrm{SO}_{4}\right)$ as well as laboratory isotopic analyses $\left(\delta^{18} \mathrm{O}\right)$ were performed on a monthly basis during the whole sampling period.

For the $\delta^{18} \mathrm{O}$ measurements, the samples were collected in $20 \mathrm{ml}$ polyethylene containers which were first rinsed in sample water several times and then filled to the top to minimise the air entrapment. For the major cation element analyses, the samples were filtered through $0.45-\mu \mathrm{m}$ filters and collected in acid-rinsed $100 \mathrm{ml}$ polyethylene bottles. For the major anion element analyses the samples were collected in $500 \mathrm{ml}$ polyethylene bottles. Once the samples were taken, they were stored in a portable fridge until they were transported to the laboratory for the analyses.

Water temperature, $\mathrm{pH}$ and specific electrical conductivity were measured in situ by WTW350i instruments with $\pm 0.1 \%$ for $\mathrm{pH}$ and $\pm 0.5 \%$ for EC reading limits. Alkalinity was determined by acid titration using methyl orange. Major ion analysis was performed photometrically in the Faculty of Geology and Geoenvironment (University of Athens, Greece). All the isotopic analyses were performed in the Isotope Hydrology Laboratory of National Center of Scientific Research (NCSR) 'Demokritos' (Athens, Greece). In particular, the stable isotope ratio of oxygen $\left({ }^{18} \mathrm{O} /{ }^{16} \mathrm{O}\right.$ ) was determined by conventional mass spectrometry (SIRA Series II) with an overall precision of $0.1 \%$. The measurements were expressed in delta $(\delta)$ notation as per mille $(\%)$ deviation from the reference Vienna Standard Mean Ocean Water (VSMOW).

The fluctuations in the seasonal concentrations have been reduced to a single number for each spring by calculating the coefficient of variation defined by the equation below:

\section{Equation 1 - Coefficient of variation}

$\mathrm{CV}=\sigma / \mathrm{X} * 100$

where $\sigma$ is the standard deviation and $\mathrm{X}$ is the arithmetic mean.

The coefficient of variation classifies the spring as conduit flow or diffuse flow type when CV is more or less than $5 \%$, respectively (Shuster and White, 1971). Values of CV less than $5 \%$ also indicate a long contact residence time of the groundwater. Coefficient of variation, determinable from the seasonal series, has been identified as a useful index of aquifer type, although Atkinson (1977) indicates that additional parameters (e.g. geomorphological characteristics) should be also taken into account in the interpretation. The carbon dioxide partial pressure $\left(\mathrm{P}_{\mathrm{CO} 2}\right)$ is an indicative parameter of the capacity of water to dissolve carbonates. Hence, higher values of $\mathrm{P}_{\mathrm{CO} 2}$ in water result in increasing the water capacity to dissolve carbonates. The determination of $\mathrm{P}_{\mathrm{CO} 2}$ has been calculated with the software package PHREEQC based on the following mass-action equation when the concentration of $\mathrm{HCO}_{3}$ and the $\mathrm{pH}$ value are known (Freeze and Cherry, 1979):

\section{Equation 2 - Mass action equation}

$$
\mathrm{K}_{\mathrm{H} 2 \mathrm{CO} 3}=\left[\mathrm{H}^{+}\right]\left[\mathrm{HCO}_{3}^{-}\right] /\left[\mathrm{H}_{2} \mathrm{CO}_{3}\right]
$$

Equation 3 - Carbon dioxide partial pressure equation

$\mathrm{P}_{\mathrm{CO} 2}=\left[\mathrm{H}_{2} \mathrm{CO}_{3}\right] / \mathrm{K}_{\mathrm{CO} 2}$

where the brackets mean ionic activity, and:

$\left[\mathrm{H}^{+}\right]$is the ionic activity of hydrogen;

$\mathrm{K}_{\mathrm{H} 2 \mathrm{CO} 3}$ is an equilibrium constant $=10^{-6.35}$ at $25^{\circ} \mathrm{C}$;

$\mathrm{K}_{\mathrm{CO} 2}$ is an equilibrium constant $=10^{-1.47}$ at $25^{\circ} \mathrm{C}$;

$\mathrm{P}_{\mathrm{CO} 2}$ is the carbon dioxide partial pressure expressed in bars or atmospheres.

XLVII, No $2-754$ 


\section{Results and Discussion}

\subsection{Water Quality}

The mean values for the physical-chemical variables analyzed in the groundwater samples are summarized in Table 2. These values have been used for groundwater quality assessment. Hence, as depicted in the Piper diagram (Figure 2), the largest number of spring waters is plotted in the left corner of the diamond-shaped field. On the metals triangle, many samples lie very close to and along the segment that connects the calcium and the magnesium ions. On the right triangle, the majority of the samples plotted in the left corner suggest a significant content in $\mathrm{HCO}_{3}$. The $\mathrm{Ca}-$ $\mathrm{HCO}_{3}$ water type predominates in the region as it characterises $81.3 \%$ of the groundwater samples. The $\mathrm{Mg}-\mathrm{HCO}_{3}$ water type is represented by $18.7 \%$ of the samples. The $\mathrm{Ca}-\mathrm{HCO}_{3}$ type refers to the groundwater samples that were taken from aquifers located in carbonate formations, sandstones and conglomerates. The $\mathrm{Mg}-\mathrm{HCO}_{3}$ type includes the spring waters that mainly discharge the ophiolitic mélange, since the presence of minerals rich in magnesium is typical for this formation (e.g. SP16).
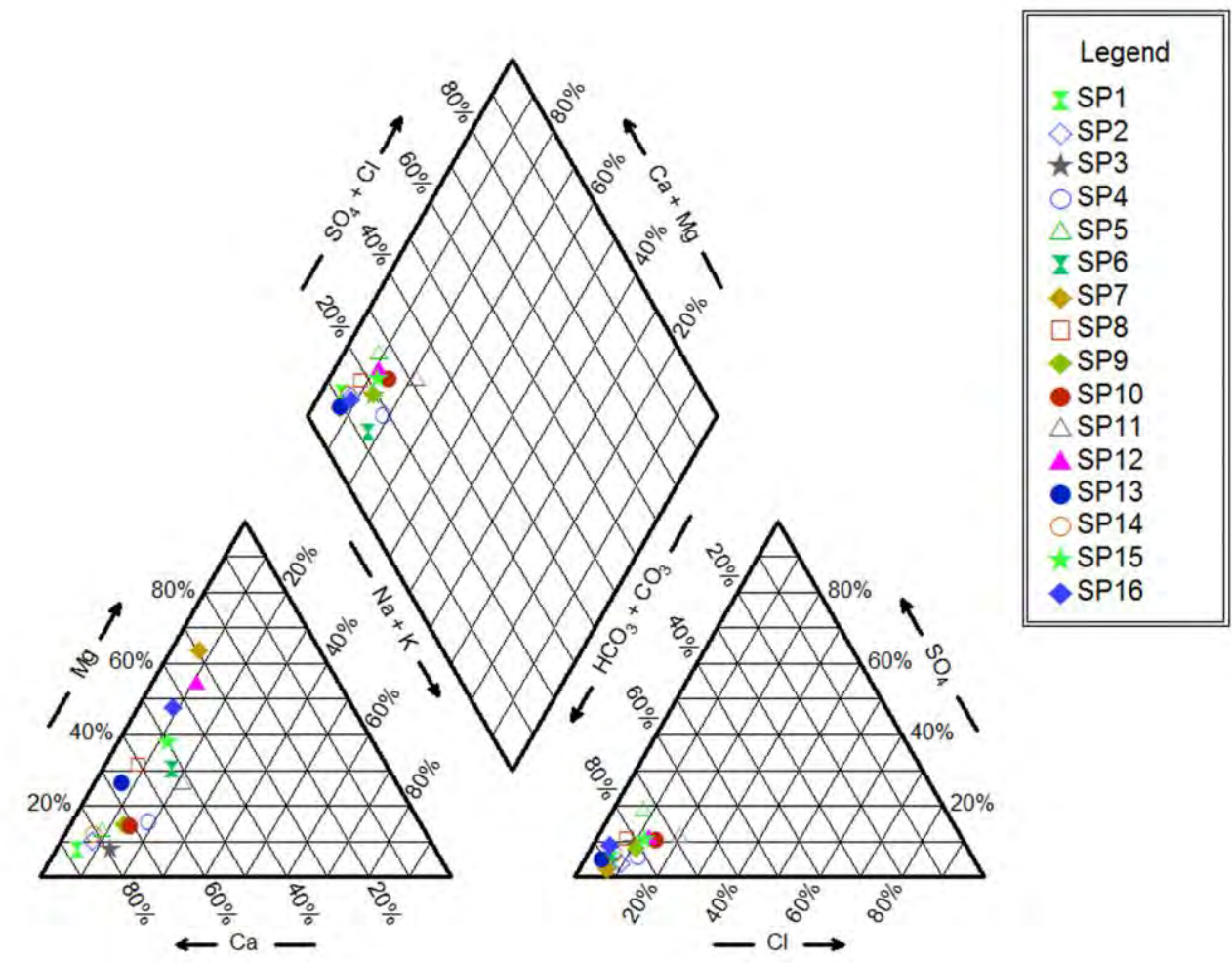

Figure 2 - Piper diagram for the definition of groundwater chemical types.

\subsection{Temporal variations}

Hydrochemographs of continuous water-quality data from springs have been widely used as indicators of aquifer characteristics (Liu et al., 2007; Andreo et al., 2002; Raeisi and Karami, 1997). In the present study, hydrochemographs of $\operatorname{LogP}_{\mathrm{CO} 2}, \delta^{18} \mathrm{O}, \mathrm{HCO}_{3}, \mathrm{pH}, \mathrm{SI}_{\text {cal }}$ and water temperature have been constructed in order to assess the hydrochemical indicators of groundwater flow. Additionally, the coefficient of variation for electrical conductivity (EC) (Table 2) has been calculated to classify springs according to the groundwater flow type occurring in the subsurface. 


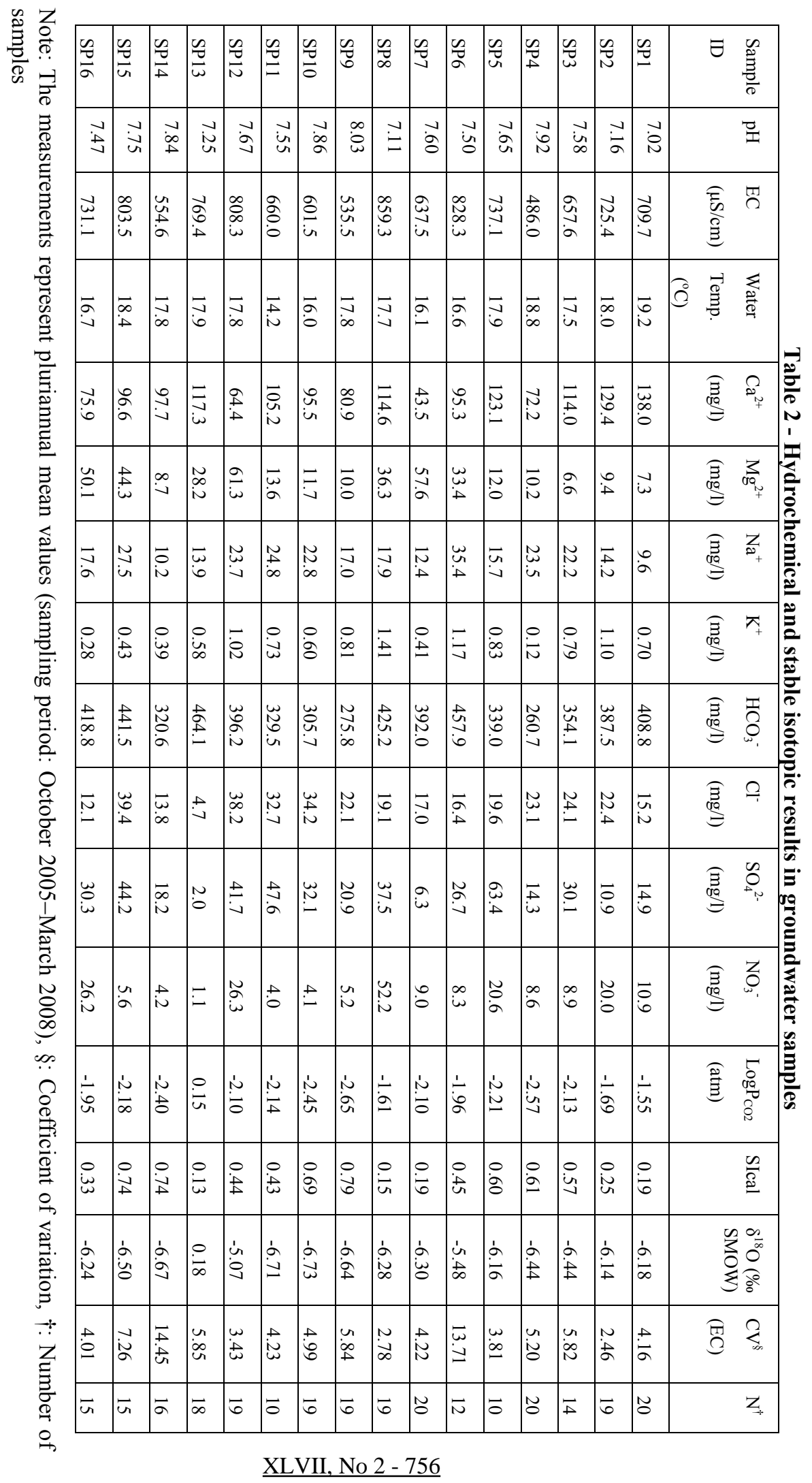


The coefficient of variation of EC values vary between $2.4 \%$ and $14.4 \%$. The majority of the springs (SP1, SP2, SP5, SP7, SP8, SP10, SP11, SP12, SP16) show CV values below 5.0\% indicating a dominant diffuse flow system in the aquifers, whereas seven springs (SP3, SP4, SP6, SP9, SP13, SP14, SP15) are characterised by CV values above 5.0\%. Electrical conductivity variance in springs SP3, SP4, SP9 and SP13 is very close to $5.0 \%$ and in combination with in situ geological and hydrogeological observations it can be assumed that the groundwater flow in these aquifers is mainly taking place through small fractures and the matrix of the rock, where the water seeps slowly. In three springs (SP6, SP14 and SP15), the CV of EC has been calculated far above the $5.0 \%$, outlining that groundwater flow is mainly occurring in conduits. Two of these springs (SP14 and SP15) are located in karstified carbonate formations, hence the assumption can be justified by the regional geology. Spring SP6 outcrops inside the ophiolitic mélange, meaning that a conduit flow system is probably not a valid assumption. In situ observations have revealed that the groundwater of the specific spring is very close to the surface, hence the water is very much affected by the atmospheric conditions. Moreover, its discharge is very small resulting in its ephemeral function and the waters been stagnant until the spring starts again its operation.

The observed variation of bicarbonate concentrations (Figure 3 ) follows more or less the seasonal pattern of $\log \mathrm{P}_{\mathrm{CO} 2}$ in a yearly cycle, with the highest values occurring in summer and the lower in winter. Several springs (e.g. SP5, SP10) tend to show their highest bicarbonate concentrations in the summer, when the highest $\log \mathrm{P}_{\mathrm{CO} 2}$ occurs; also expected when considering equations 2 and 3 . This is attributed to the fact that the $\mathrm{CO}_{2}$ partial pressure in water is strongly related to the transpiration by plant roots and microbes in the soils. In summer, root transpiration in soil is stronger and carbon dioxide is more generated (Liu et al., 2007; Liu et al., 2006; Atkin et al., 2000), hence this explains the seasonal change. However, there are springs (e.g. SP6, SP14) where the highest $\log \mathrm{P}_{\mathrm{CO} 2}$ and bicarbonate values occur in the early wet period which can be related to the flushing of soluble components stored during the earlier dry periods which are washed out by the first recharge events (Khayat et al., 2008; Bakalowicz et al., 1974).

In most cases, the groundwater in aquifers is close to saturation with respect to calcite (Figure 3); hence the majority of the springs are calcite supersaturated. Only when the groundwater is decreased in $\mathrm{pH}$ or enriched in $\mathrm{CO}_{2}$, the spring waters show lower Saturation Index with respect to calcite. Calcite supersaturation during the rainy season is controlled by variations of $\mathrm{pH}$ in the recharge events. Therefore, seasonal variations are not easily observed. Typically, saturation of calcite can be reached at the beginning of a rainy season (Khayat et al., 2008) and that is the case

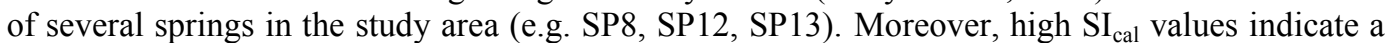
solution rate decrease and a longer residence of water in the aquifer which can be attributed to low flow capacities (Jacobson and Langmuir, 1974).

The stable isotopes contribute in the investigation of the groundwater circulation as the stable isotopic content is very much affected by temperature variations resulting in fractionation phenomena. Hence, the lowest and highest $\delta^{18} \mathrm{O}$ values are observed in lowest and highest water temperatures, respectively (Clark and Fritz, 1997). In the study area, the measured $\delta^{18} \mathrm{O}$ values of the spring waters reflect seasonal variations typical for the northern hemisphere with minimum values in winter and maximum values in summer (Figure 3). However, the $\delta^{18} \mathrm{O}$ values of September 2006 are more negative than expected which can be attributed to a heavy recharge event which is typically exhausted relative to the $\mathrm{H}_{2}{ }^{16} \mathrm{O}$, resulting in relatively low $\delta^{18} \mathrm{O}$ values (Clark and Fritz, 1997). Moreover, the fluctuations of $\delta^{18} \mathrm{O}$ values can be regarded as weak indicating of good mixing of infiltrated and ground waters. 

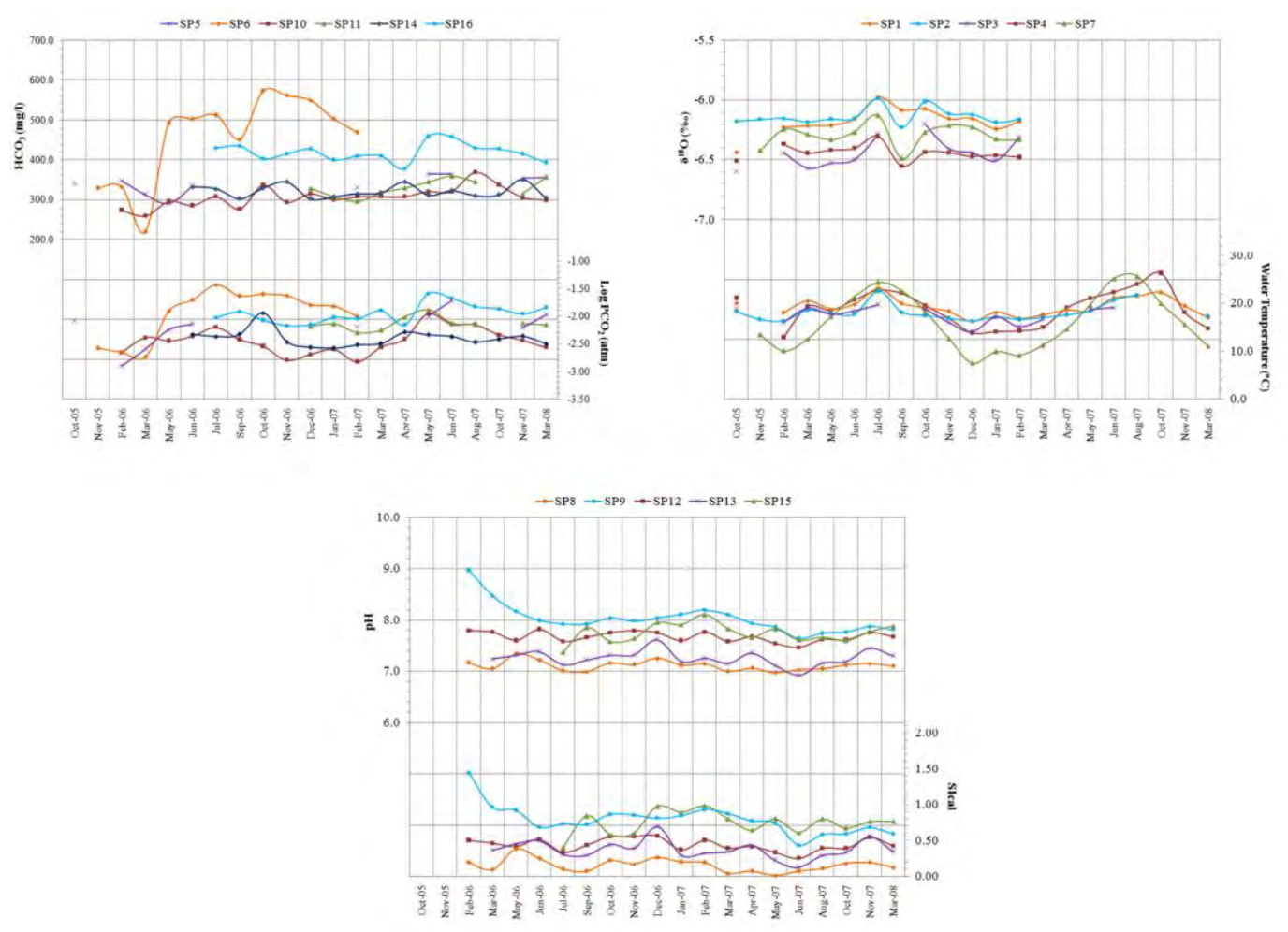

Figure 3 - Temporal variations of physical-chemical and isotopic parameters.

\section{Conclusion - Remarks}

Natural discharge of flow systems in Argolis peninsula occur through a number of small discharge springs because of stratigraphic or structural features. This paper presents the seasonal variations of three hydrological year continuous physical-chemical and isotopic data from these springs through the construction of representative hydrochemographs and the determination of the coefficient of variation. These variations were found for $\mathrm{pH}$, electric conductivity, $\mathrm{CO}_{2}$ partial pressure, $\mathrm{HCO}_{3}$ and calcite saturation of the springs. The results have shown that the diffuse flow type characterises the majority of the springs while the karstic springs are mainly related to conduit flow system.

Temporal variations of data have also revealed the strong correlation between stable isotopic values and the water temperature, as the $\delta^{18} \mathrm{O}$ values become more positive in the summer and more negative in the winter. The bicarbonate values follow more or less the variation of $\log \mathrm{P}_{\mathrm{CO} 2}$ in a yearly cycle, indicating that the $\mathrm{CO}_{2}$ partial pressure in water is strongly related to the transpiration by plant roots and microbes in the soils, while the opposite is related to the flushing of soluble components stored during the earlier dry periods which are washed out by the first recharge events. Moreover, the majority of the springs are supersaturated with respect to calcite and strongly correlated to $\mathrm{pH}$ variations. Supersaturation of calcite, which indicates a longer residence time, is mainly reached at the beginning of a rainy season.

\section{Acknowledgements}

The author would like to thank the director as well as the personnel of the Isotope Hydrology Laboratory of NCSR 'Demokritos' (Athens) for providing the stable isotope analyses. 


\section{References}

Andreo B., Carrasco F., Bakalowicz M., Mudry J. and Vadillo I. 2002. Use of hydrodynamic and hydrochemistry to characterise carbonate aquifers. Case study of the Blanca-Mijas unit (Malaga, southern Spain), Environmental Geology, 43: 108-119 pp.

Aranitis S. 1963. Die Entstehung der Eruptivgesteine vom Hermioni-Gebiet und die mit ihnen verbundene Vererzung, Ann Geol Pays Hell, 14: 211 pp.

Atkin O.K., Edwards E.J. and Loverys B.R. 2000. Response of root respiration to changes in temperature and its relevance to global warming, New Phytologist, 147: 141-154 pp.

Atkinson T.C. 1977. Diffuse flow and conduit flow in limestone terrain in the Mendip Hills, Somerset (Great Britain), Journal of Hydrology, 35: 95-110 pp.

Bakalowicz M., Blavoux B. and Mangin A. 1974. Apports du tracage isotopique naturel a la connaissance du fonctionnement d'un systeme karstique-teneurs en oxygen-18 de trios systems des Pyrenees, France, Journal of Hydrology, 23: 141-158 pp.

Baumgartner P.O. 1985. Jurassic Sedimentary Evolution and Nappe Emplacement in the Argolis Peninsula (Peloponnesus, Greece), Mém Soc Helv Sci Nat., 99 (1): 137 pp.

Clark I.D. and Fritz P. 1997. Environmental Isotopes in Hydrogeology, Lewis Publishers, New York, $328 \mathrm{pp}$.

Clift P.D. and Robertson H.F. 1989. Evidence of a Late Mesozoic Ocean Basin and SubductionAccretion in the Southern Greek Neo-Tethys, Geology, 17: 559.

Decrouez D. 1975. Étude stratigraphique et micropaléontologique du Crétacé d'Argolide (Péloponnèse, Grèce), PhD Thesis: University of Geneva.

Freeze R.A. and Cherry J.A. 1979. Groundwater, Prentice-Hall, Englewood Cliffs, New Jersey.

Fytikas M., Innocenti F. and Mazzuoli R. 1980. Methana Sheet - Geological Map in Scale 1:50000, IGME, Athens, Greece.

Gabrovsek F. and Dreybrodt W. 2001. A model of the early evolution of karst aquifers in limestone in the dimensions of length and depth, Journal of Hydrology, 240: 206-224 pp.

Gaitanakis P. and Photiades A.D. 2007. Spetses Sheet - Geological Map in Scale 1:50000. IGME, Athens, Greece.

Gaitanakis P. and Photiades A.D. 1993. New Data on the Geology of Southern Argolis (Peloponnesus, Greece), Bull Geol Soc Greece, 28: 247 pp.

Gaitanakis P. and Photiades A.D. 1991. Geological Structure of SW Argolis (Peloponnesus, Greece), Bull Geol Soc Greece, 25: 319 pp.

Jacobson R.L. and Langmuir D. 1974. Controls on the quality variations of some carbonate spring waters, Journal of Hydrology. 23: 247-265 pp.

Kantas K. 1991. Hydrogeological Explanation of Salt-Water Intrusion in Karstic Aquifers in the NE Argolis Limestones (Peloponnesus, Greece), Bull Geol Soc Greece, 25: 183 pp.

Khayat S., Möller P Geyer S., Marei A., Siebert C. and Hilo F.A. 2008. Hydrochemical variation in the springs water between Jerusalem-Ramallah Mountains and Jericho Fault, Palestine. Environ Geol, 57: 1739-1751 pp.

Kresic N. 2007. Hydrogeology and Groundwater Modeling, 2nd ed., CRC Press, Boca Raton, FL, $805 \mathrm{pp}$.

Liu Z., Li Q., Sun H. and Wang J. 2007. Seasonal, diurnal and storm-scale hydrochemical variations of typical epikarst springs in subtropical karst areas of SW China: Soil $\mathrm{CO}_{2}$ and dilution effects, Journal of Hydrology, 337: 207-223 pp.

Liu Z., Li Q., Sun H., Liao C., Li H., Wang J. and Wu K. 2006. Diurnal variations of hydrochemistry in a travertine-depositing stream at Baishuitai, Yunnan, SW China. Aquatic Geochemistry, 12: 103-121 pp.

Matiatos I. and Alexopoulos A. 2011. Application of stable isotopes and hydrochemical analysis in groundwater aquifers of Argolis Peninsula (Greece), Isotopes in Environmental and Health Studies, 47 (4), 512-529 pp.

Newson M.D. 1972. Comments on seasonal fluctuations in the chemistry of limestone springs, by Shuster, E.T. and White, W.B. Journal of Hydrology, 16: 49-51 pp.

XLVII, No $2-759$ 
Photiades A.D. and Ecomomou G.S. 1991. Alteration hydrothermale sous-marine des basaltes et des dolerites (facies zeolitique) de l'unité moyenne 'volcanique' de l'Argolide septentrionale (Péloponnèse, Grèce), Bull Geol Soc Greece, 25: 301 pp.

Photiades A.D. and Keay S. 2000. Mid-Late Jurassic Granodiorite Basement in Southern Argolis Peninsula (Greece), Tectonostratigraphic Implications, in Proceedings of the 3rd International Conference on the Geology of the Eastern Mediterranean, edited by I. Panayides et al. Geological Survey Department, Lefkosia, Cyprus, 2000, 233-239 pp.

Raeisi E. and Karami G. 1997. Hydrochemographs of Berghan karst spring as indicators of aquifer characteristics, Journal of Cave and Karst Studies, 59(3): 112-118 pp.

Renz C., 1906. Trias und Jura in der Argolis. Z. dtsch. geol. Ges., 58: 379-395 pp.

Shuster E.T. and White, W.B. 1971. Seasonal fluctuations in the chemistry of limestone springs: a possible means for characterizing carbonate aquifers, Journal of Hydrology, 14: 93-128 pp.

Singhal B.B.S. and Gupta R.P. 2010. Applied Hydrogeology of Fractured Rocks, 2nd Edition, Springer, $408 \mathrm{pp}$.

Ternan J.L. 1974. Comments on the use of calcium hardness variability index on the study of carbonate aquifers: with reference to central Pennines, England, Journal of Hydrology, 16: 317-334 pp.

White W.B. 2007. Groundwater Flow and Transport in Karst, in The Handbook of Groundwater Engineering edited by J.W. Delleur, CRC Press, Boca Raton, FL, 18-1 to 18-36 pp. 